\title{
A Igreja Católica e o Povo Judeu: \\ Do ressentimento ao reconhecimento
}

\author{
The Catholic Church and the Jewish people: \\ from resentment to recognition
}

\author{
MARCial MAÇANEIRO (iDa \\ Cirlene CRISTina de SOUSA (id b
}

\section{Resumo}

Este artigo trata das relações entre a Igreja Católica e o povo judeu, examinando o antissemitismo como fato teológico, à luz dos trágicos eventos da Segunda Guerra Mundial. Neste contexto, o Holocausto desponta como a materialização político-ideológica do ódio aos judeus, caracterizado como antissemitismo moderno. Esta forma de antissemitismo leva aos extremos do extermínio os ressentimentos antijudaicos da Cristandade, que remontam às controvérsias hebraico-cristãs dos séculos III-IV d.C., marcando posteriormente toda a Idade Média. Autores como Gundlach, Isaac e Heschel iluminam a reflexão, com especial atenção à interlocução judaico-católica dos anos 40 a 60 , nas proximidades do Concílio Vaticano II. Este evento, particularmente, demarca uma guinada teológica nas relações da Igreja em face dos judeus, com a condenação do antissemitismo e o reconhecimento das raízes judaicas do Cristianismo. A partir do Concílio Vaticano II (cf. Nostra Aetaten. 4), são apresentados os documentos do Diálogo Judaico-Católico já publicados, com seus resultados e diretrizes para a Teologia, a Liturgia e a Catequese católicas. Conclui-se que a consciência do Holocausto e a consciência das raízes judaicas da Igreja marcam o percurso comum de judeus e cristãos, nos dias de hoje, comprometidos com a verdade, a justiça e paz.

Palavras-chave: Antissemitismo. Diálogo judaico-católico. Nostra Aetate. Igreja e Israel.

a Pontifícia Universidade Católica do Paraná (PUCPR), Curitiba, PR, Brasil. Doutor em Teologia, e-mail: marcialscj@gmail.com

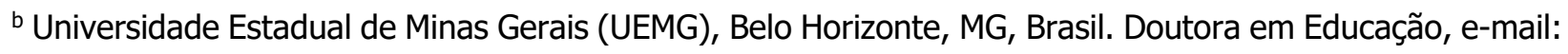
cirlenesousa@yahoo.com.br 


\section{Abstract}

This article deals with the relationship between the Catholic Church and the Jewish people, examining anti-Semitism as a theological fact, in the light of the tragic events of World War II. In this context, the Holocaust emerges as the political-ideological materialization of the hatred of Jews, characterized as modern anti-Semitism. This form of anti-Semitism takes Christianity's antiJewish resentments to the extremes of extermination, which date back to the Hebrew-Christian controversies of the 3rd-4th century AD, later marking the entire Middle Ages. Authors such as Gundlach, Isaac and Heschel illuminate the reflection, with special attention to the Jewish-Catholic dialogue from the 1940s to the 60s, in the vicinity of the Second Vatican Council. This event, indeed, marks a theological shift in the Church's relations with the Jews, with the condemnation of anti-Semitism and the recognition of the Jewish roots of Christianity. Starting with the Second Vatican Council (cf. Nostra Aetate n. 4), the documents of the Jewish-Catholic Dialogue already published are presented, with their results and guidelines for Catholic Theology, Liturgy and Catechesis. We conclude that awareness of the Holocaust and awareness of the Jewish roots of the Church today mark the common journey of Jews and Christians, committed to truth, justice, and peace.

Keywords: Anti-Semitism. Jewish-Catholic Dialogue. Nostra Aetate. Church and Israel.

\section{Introdução}

O termo antissemitismo, geralmente referido ao povo hebreu, é etimologicamente impróprio, neste caso, visto que também árabes, sírios, palestinos e caldeus são semitas. Contudo, a referência aos judeus e ao judaísmo é uso consagrado, adotado nos discursos e documentos oficiais, históricos, sociais ou religiosos. Desde seu aparecimento entre 1879 e 1880 na pena do jornalista alemão Wilhelm Marr (cf. MARR, 1880), o termo se consolidou no uso acadêmico e midiático, a substituir pouco a pouco a palavra alemã Judenhass (ódio aos judeus). Isso operou um ajuste terminológico, mas não moral ou político, visto que o ódio aos judeus continuou a marcar a compreensão do que seja o antissemitismo, como observa Bauman:

Em aplicações práticas, no entanto, a controvérsia semântica [do termo] foi no geral evitada e o conceito focalizou sem erro o alvo pretendido. "Antissemitismo" representa o ressentimento contra os judeus. Refere-se à concepção dos judeus como um grupo estranho, hostil e indesejável e às práticas que derivam dessa concepção e a sustentam. (BAUMAN, 1998 , p. 54) 
A concepção dos judeus como grupo estranho à Nação se acentuou na Modernidade, mas tem raízes medievais na rejeição dos judeus como povo estranho à Cristandade, não só em termos nacionais, mas teológicos: os judeus eram tidos como culpados da morte de Cristo, dignos de suspeita por parte da Igreja e das Monarquias.

\section{Suspeita e ressentimento antijudaicos}

A acusação de deicídio imputava aos judeus a culpa coletiva pela morte de Jesus - ainda que o Credo diga claramente que Ele “padeceu sob Pôncio Pilatos” (DZ n. 7)”, num processo promovido pela facção dos saduceus e o Sinédrio. Da culpa de deicídio brotaram duas teorias antijudaicas: Israel teria sido cancelado do plano da salvação e substituído pela Igreja (teoria da substituição); os judeus seriam amaldiçoados a vagar sem rumo na terra, até que, no fim dos tempos, alguns deles se convertam a Jesus e ingressem na Igreja (sentença da maldição). Ainda que essas teorias não tenham recebido anuência dogmática oficial, eram aceitas como opiniões teológicas válidas, com base nas controvérsias judaico-cristãs dos autores patrísticos (cf. RIES, 1992, p. 279-290).

Enquanto a Igreja não reviu esta opinião com sólido exame bíblico e histórico, a acusação de deicídio e a teoria da substituição causaram grandes prejuízos ao povo judeu, especialmente na Europa: perda de direitos, segregação, expulsão de vários países, perseguição e morte. Isso pesou psicológica e politicamente no ressentimento antijudaico europeu, a tal ponto que, em 1928, o Santo Ofício foi a público com esta Nota da parte da Santa Sé:

Por reprovar todos os ódios e animosidades entre os povos, a Sé Apostólica condena acima de tudo [maxime] o ódio contra o povo judeu outrora escolhido por Deus, ódio que hoje se costuma comumente designar com o nome de antissemitismo. (SANTO UFFICIO, 1928, p. 104)

Este é o primeiro pronunciamento oficial da Igreja Católica a usar o termo "antissemitismo" definido como “ódio contra o povo judeu”. Assim, a Nota estabelece um critério moral de fronteira entre as controvérsias judaicas no plano intelectual e

${ }^{1}$ DZ é sigla convencional do compêndio de Símbolos de fé e definições do Magistério, editado por $\mathrm{H}$. Denzinger. 
financeiro, de um lado, e as manifestações de ódio, de outro, que são inaceitáveis para os cristãos porque contradizem o amor evangélico (cf. Mt 5,43-48). Entretanto, o sentimento antijudaico estava muito arraigado, nos meios cristãos, para ser desfeito por uma Nota de poucas linhas.

Os ressentimentos eram notórios na pregação e na liturgia: até 1958 o rito romano da Sexta Feira Santa considerava os judeus "pérfidos", "obcecados" e "envoltos em trevas" (Missale Romanum, 1950, p. 201-202)² - expressões abolidas pelo Papa João XXIII em 1959. Em suma, o antissemitismo moderno é um fato político, sem deixar de ser um "fato teológico" (ISAAC, 1986, p. 237), ainda que, em termos históricos, "seria um delírio reduzir os antijudaísmos remanescentes ao antissemitismo que levou a Auschwitz" (MORIN, 2007, p. 76).

\section{Gundlach, Pio XI e a encíclica "Mit brennender sorge"}

No início do século XX - antes do Holocausto perpetrado pelo regime nazista vários autores distinguiam o que seria "controvérsia hebraico-cristã", "ódio antijudaico" ou "antissemitismo" (RIES, 1992, p. 299; ARENDT, 2016, p. 203). É o caso emblemático de Gustav Gundlach antes da Segunda Guerra Mundial, em seu verbete "Antissemitismo" publicado no prestigioso Lexikon für Theologie und Kirche (LTK) em 1930.

$\mathrm{Na}$ época, Gundlach distinguia "duas tendências de antissemitismo: uma nacional e político-racial; a outra, político-estatal” (GUNDLACH, 1930, p. 504). A primeira tendência é "o antissemitismo de tipo racista e étnico, incompatível com o ensinamento da Igreja"; pois "combate os homens [= os judeus] unicamente em razão da diferença de sua nacionalidade, e não em razão de suas ações" (1930, p. 504). Este tipo de antissemitismo é "contrário ao amor ao próximo" e "volta-se necessariamente contra o cristianismo, em razão de seu elo interno com a religião do povo judeu, outrora eleito por Deus" (1930, p. 505). A segunda tendência é "um antissemitismo se não inteiramente cristão, porém em certa medida aceitável pela Igreja - que visa a preservar a sociedade cristã, por meios morais e legislativos, da nefasta influência dos hebreus na vida dos cristãos" (1930, p. 504).

\footnotetext{
${ }^{2}$ No rito latino de Pio V em uso, a Oração Universal da Sexta Feira Santa mencionava: perfidis judaeis (pérfidos judeus), judaicam perfidiam (perfídia judaica), obcaecatione (obsessão) e tenebris (trevas). 
Gundlach supõe que o antissemitismo "aceitável" seja circunscrito ao Direito: "devem ser excluídas as leis de exceção contra os cidadãos judeus enquanto judeus, e isto deve ser acatado do ponto de vista do Estado moderno de Direito" (1930, p. 505). Dentro desses limites, ele admitia que o Estado aplicasse os "meios morais e legislativos" para "preservar a sociedade cristã" da "nefasta influência dos hebreus" no terreno da "economia privada moderna" (1930, p. 504-505). Notemos que Gundlach não invoca argumentos teológicos; fala apenas do Estado e insiste que o "antissemitismo de tipo racista e étnico" é "incompatível com o ensinamento da Igreja" (1939, p. 504) - numa referência explícita à Nota do Santo Ofício de 1928 que reprovou o "ódio contra o povo judeu" (SANTO UFFICIO, 1928, p. 104).

Fazendo jus à História, importa dizer que a partir de 1937 Gundlach se confrontou com fatos novos, que o levaram a reagir: a publicação da encíclica Mit brennender sorge de Pio XI contra a ideologia racista de Hitler (1937), e o apoio de setores eclesiásticos à política do III Reich na Áustria (1938). Quanto ao primeiro fato: em 1937 o Papa Pio XI publica a encíclica Mit brennender sorge - escrita propositalmente em alemão - cujo título significa "com urgente preocupação" (PIO XI, 1937). Nesta Carta, Pio XI tratou da guerra e posicionou-se contra o Nazismo. No mesmo ano, de 17 a 21 de março, exemplares da encíclica foram distribuídos a todas as igrejas católicas presentes no território do Reich, onde foi lida, causando comoção, como atesta De Lubac: "Toda aquela multidão, que ouvia a leitura do documento pontifício em atitude de oração, não podia mais dar-se por iludido sobre a gravidade do seu conteúdo e de suas consequências" (1990, p. 30). Ora, a encíclica Mit brennender sorge impactou o jesuíta e sociólogo Gundlach, cuja reflexão tinha contribuído à redação da encíclica Quadragesimo Anno de Pio XI, em 1931 (cf. PASSELECQ; SUCHECKY, 1998, p. 115).

Quanto ao segundo fato: Gundlach soube do apoio público de bispos austríacos à anexação da Áustria à Alemanha - o que ameaçava a autonomia da Igreja Católica no país - e foi à Rádio Vaticano em língua alemã, no dia $1^{\circ}$ de abril de 1938, fazer sua crítica de viva voz. No dia seguinte, sua fala aparece transcrita na edição impressa do jornal L'Osservatore Romano (GUNDLACH, 1938). No artigo, ele classificou o apoio dos bispos ao III Reich de "falso catolicismo político" assumido por mentes "fascinadas pelo poder e sucesso do momento" (GUNDLACH, 1938, apud PASSELECQ; SUCHECKY, 1998, p. 123). 
Em julho do mesmo ano (1938), Gustav Gundlach recebe do Papa Pio XI a missão sigilosa de redigir o projeto de outra encíclica - junto aos colegas jesuítas Gustave Desbuquois e John LaFarge - na qual se afirmará a unidade do gênero humano contra as teses racistas, pseudocientíficas e xenófobas do nazismo. Esta encíclica, intitulada justamente Humani generis unitas chegou à primeira versão em setembro de 1938; mas, com a morte de Pio XI em fevereiro de 1939, o projeto se perdeu³.

\section{Os Dez Pontos de Seelisberg}

Quanto ao sentimento antijudaico, já mencionamos a acusação generalizada de deicídio, a sentença de maldição e a teoria da substituição de Israel pela Igreja Cristã, que - apesar das inconsistências bíblicas e históricas - se estabeleceram como "mito teológico" a partir do século IV, perdurando em toda a Idade Média (ISAAC, 1966, p. 33). Desde então, essas opiniões teológicas fundamentaram o "ensino do desprezo aos judeus" na Cristandade, a fincar cada vez mais "as raízes cristãs do antissemitismo" no Ocidente (ISAAC, 1966, p. 9). Séculos depois da Idade Média e no término das duas Grandes Guerras, a consciência do Holocausto convida judeus e cristãos a "uma obra de purificação: extirpar essas raízes e instaurar o ensino da estima" - propõe Isaac (1966, p. 9).

Extirpar as raízes do antissemitismo e educar à estima são as proposições que o mesmo Isaac, apoiado por Maritain, levou à Conferência de Seelisberg (Suíça), em 1947. Esta Conferência reuniu representantes judeus, católicos e protestantes de variadas expressões confessionais, vindos de 19 países. O evento reforçou a fundação do International Council of Christians and Jews (ICCJ) e resultou nos Dez Pontos de Seelisberg:

1. Deve ser relembrado que um só e mesmo Deus nos fala no Antigo e no Novo Testamento.

2. Não se pode esquecer que Jesus nasceu de mãe judia, pertencia à família de Davi e ao povo de Israel, e que seu amor eterno abrange o seu povo e o mundo inteiro.

3. Recorde-se ainda que os primeiros discípulos, os Apóstolos, e os primeiros mártires eram judeus.

\footnotetext{
${ }^{3}$ Além das complicações de segurança e de comunicação entre os redatores, no cenário da Guerra, a redação seguia em sigilo; segundo alguns testemunhos históricos, o novo pontífice, Pio XII, não tinha conhecimento do projeto desta nova encíclica (cf. PASSELECQ; SUCHECKY, 1998, p. 148-156).
} 
4. Tenha-se presente que o principal mandamento do cristianismo, o amor de Deus e do próximo, anunciado no Antigo Testamento e confirmado por Jesus, obriga igualmente, cristãos e judeus, em todas as relações humanas.

5. Deve-se evitar diminuir o judaísmo bíblico e pós-bíblico para exaltar o cristianismo.

6. Não se deve empregar a palavra "judeu" para designar exclusivamente os inimigos de Jesus, e as palavras "inimigos de Jesus" para designar o povo judeu em seu conjunto.

7. Não se deve apresentar a Paixão de Jesus, como se todos os judeus, ou somente os judeus, tivessem incorrido na odiosidade da crucificação. Não foram todos os judeus que pediram a morte de Jesus, nem foram somente judeus que se responsabilizaram por ela. A Cruz, que salva a humanidade, revela que Cristo morreu pelos pecados de todos. Pais e mestres cristãos deveriam ser alertados a respeito de sua grande responsabilidade na maneira de narrar os sofrimentos de Jesus. Se o fazem de uma forma superficial, correm o risco de fomentar aversões no coração das crianças ou dos ouvintes. Numa mente simples, movida de um ardente amor compassivo pelo Salvador crucificado, o horror natural dos perseguidores de Jesus pode facilmente tornar-se, por motivos psicológicos, ódio indiscriminado pelo judeu de todos os tempos, inclusive nos nossos dias.

8. Não se devem evocar as condenações bíblicas e o grito da multidão enraivecida: "Que seu sangue caia sobre nós e sobre nossos filhos" (Mt 27,25) sem relembrar que esse grito não anulou as palavras de nosso Senhor, de consequências incomparavelmente maiores: "Pai, perdoa-lhes; eles não sabem o que fazem" (Lc 23,24).

9. É preciso evitar qualquer tentativa de mostrar os judeus como um povo reprovado, amaldiçoado e sentenciado a um sofrimento perpétuo.

10. Deve ser mencionado que os primeiros membros da Igreja eram judeus. (CCDEJ 2020)

Como se nota, esses Dez Pontos prospectam a extensa tarefa de revisão histórica, exegética, hermenêutica, teológica e catequética a respeito do povo Judeu e de Israel no plano da salvação, levando as Igrejas Cristãs a reencontrar-se com o judeo-cristianismo original dos séculos I-II d.C. Tarefa posta em ação pelas diferentes confissões cristãs, que continuaram filiadas ao International Council of Christians and Jews até o presente, com novas instâncias de interlocução e resultados no campo bíblico, teológico, educativo e social (cf. ICCJ, 2011).

\section{As interlocuções, rumo ao Concílio}

Desde a Conferência de Seelisberg em 1947, havia-se incrementado a interlocução entre representantes do Judaísmo e da Igreja Católica. Isto se intensificou nos anos que antecederam o Concílio Vaticano II, com a colaboração de peritos e o apoio do Papa João XXIII, seguido por Paulo VI. De fato, a comunidade judaica foi ouvida no processo de redação de um documento conciliar sobre os Judeus e o Judaísmo, que resultou na Declaração Nostra Aetate n. 4, publicada em 1965. Nos anos anteriores, de 1961 a 1964, o Papa João XXIII confiou ao Cardeal Augustin Bea a missão 
de dialogar com as organizações judaicas internacionais. Era importante ouvir o parecer dessas organizações a respeito do que consideravam relevante para os debates do Concílio e o futuro das relações judaico-católicas. O Cardeal Bea consultou o American Jewish Committee, a Anti-Defamation League e a World Conference of Jewish Organizations, além de manter conversações com Nahum Goldmann, Marc Tanenbaum e Abraham Heschel, rabinos com reconhecida liderança4.

Enquanto alguns líderes judeus preferiam abordar o antissemitismo com enfoques "seculares" - pois não consideravam viável naquele momento o "diálogo religioso" com a Igreja - outros reivindicavam uma revisão da "doutrina e do ensino católico" concernente aos judeus e ao Judaísmo, inclusive "os textos litúrgicos da Semana Santa, os livros de catequese" e os "sermões e impropérios" contra os judeus, baseados em argumentos da Patrística, "em particular de Agostinho" (ANDREVON, 2013, p. 221-225). Solicitavam esta ampla revisão teológica, além do já citado Jules Isaac, os membros do American Jewish Committee e o rabino Abraham Heschel, cada qual com seu memorandum enviado por escrito à Santa Sé em 1961 e 1962, respectivamente (cf. ANDREVON, 2013, p. 228-230).

A aproximação entre judeus e cristãos em torno do Concílio Vaticano II abriu tantas perspectivas para o diálogo católico-judaico que a Declaração Nostra Aetate $\mathrm{n}$. 4 tornou-se mais um ponto de partida que um ponto de chegada. Para dar continuidade aos encontros e esclarecer, a partir do Concílio, as questões históricoteológicas levantadas por Isaac, Heschel e o American Jewish Committee, foram criadas duas instâncias, em funcionamento até o presente: em 1970, o Comitê Internacional Católico-Judaico de Ligação, para manter a "ligação" (liaison) da Igreja Católica com as organizações judaicas internacionais, das várias correntes do Judaísmo, reunidos no International Jewish Committee on Interreligious Consultations (IJCIC); depois, em 1974, Paulo VI instituiu a Comissão para as Relações Religiosas com o Judaísmo (CRRJ), que desenvolve os diálogos temáticos e os documentos judaico-católicos decorrentes.

\section{A "guinada teológica" do Concílio Vaticano II}

\footnotetext{
${ }^{4}$ Dados verificados pela pesquisadora Thérèse Marie Andrevon, a partir das Atas do Concílio Vaticano II e documentos referentes à redação de Nostra Aetate conservados no Arquivo Apostólico do Vaticano (antigos Arquivos Secretos); cf. ANDREVON, 2013, p. 219-223.
} 
Como diz o documento Porque os dons e o chamado de Deus são irrevogáveis (DCl, 2016, o Concílio Vaticano II realizou uma "guinada teológica" (DCI n. 39) na posição da Igreja face aos judeus, ao publicar, em 1965, a Declaração Nostra Aetate (NA)5:

A Igreja, que reprova toda perseguição contra quaisquer homens, lembrada do comum patrimônio com os judeus, não por motivos políticos, mas impelida pelo santo amor evangélico, deplora os ódios, as perseguições, as manifestações anti-semitas, em qualquer tempo e por qualquer pessoa, dirigidas contra os judeus. (NA $4 \mathrm{~g}$ )

Ademais, a Declaração conciliar refuta a teoria da substituição de Israel pela Igreja, ao recordar que "pertencem a Israel a adoção filial, a glória, a aliança, a legislação, o culto de Deus e as promessas, bem como os patriarcas (Rm 9,4-5)" (NA 4c). Ainda que "os judeus, em grande número, não aceitaram o Evangelho", são perpetuamente "amados" por Deus, porque "Ele não se arrepende dos dons e da vocação" concedidos a Israel (NA 4d), como atesta claramente o rabino e apóstolo Paulo: "Os dons e o chamado de Deus [para Israel] são irrevogáveis" (Rm 11,19). Portanto, o Povo de Israel preserva hoje seu lugar no plano de Deus. Também é refutada a acusação de deicídio feita aos judeus através dos séculos: "Se bem que os príncipes dos judeus e alguns de seus seguidores insistiram na morte de Cristo, aquilo que se perpetrou na Sua Paixão não pode indistintamente ser imputado a todos os judeus que então viviam, nem aos de hoje" (NA 4f).

Desta revisão emergem algumas diretrizes para o estudo bíblico, a catequese e a pregação na Igreja Católica: embora a Igreja creia ser o novo Povo de Deus, alicerçado na aliança messiânica e universal estabelecida por Jesus, "os Judeus, no entanto, não devem ser apresentados como se fossem condenados por Deus, nem amaldiçoados, como se isso decorresse das Sagradas Escrituras" (NA 4f). Portanto "haja o cuidado, da parte de todos, para que tanto na catequese como na pregação da Palavra de Deus, não se ensine algo que não corresponde à verdade evangélica, nem ao espírito de Cristo" (NA 4f).

${ }^{5}$ Indicada pela sigla NA; para o texto integral cf. CONCÍLIO VATICANO II, 1991, p. 617-625 [numeração marginal 1578-1596]. 
A estrada aberta por Nostra Aetate n. 4 avançou substancialmente com o trabalho do Comitê de Ligação e da Comissão para as Relações Religiosas com o Judaísmo. Assim, de 1965 até 2015 foram publicados quatro importantes documentos:

\section{a) Notas para uma correta apresentação dos Judeus e do Judaísmo na pregação e na catequese da Igreja Católica $(1985)^{6}$}

É um documento da Comissão para as Relações Religiosas com o Judaísmo (Vaticano), no pontificado de João Paulo II. As Notas para uma correta apresentação dos Judeus e do Judaísmo na pregação e na catequese da Igreja Católica (1985) destinamse ao ensino de crianças, jovens e adultos. É um documento didático e normativo, para a catequese, a homilia, o ensino religioso, a educação teológica e a formação pastoral.

As recomendações partem da unidade da História da Salvação, que aproxima o Antigo e o Novo testamentos; de modo que a pregação de Jesus e dos Apóstolos se baseia na Lei e nos Profetas judaicos, não cancelando-os, mas cumprindo-os em perspectiva messiânica. Deve-se fazer atenção, ainda, à apresentação por vezes hostil dos personagens israelitas no Novo Testamento. Isto pode ser compreendido no quadro das polêmicas a respeito de Jesus, com facções judaicas distintas entre si, num período de progressivo distanciamento entre a Sinagoga e a Igreja. Além disso, os Evangelhos têm expressões de apreço por Abraão, Moisés, os Profetas, a Torá, a Aliança e o culto israelita do Deus Único. O Novo Testamento testemunha as raízes judaicas do Cristianismo, que dá aos gentios o acesso "à seiva" da "antiga videira", que é Israel (Rm 11,17-19).

As Notas esclarecem que a morte de Jesus aconteceu sob o governo romano de Pôncio Pilatos, instigado pelos chefes dos sacerdotes (saduceus): estes temiam que o movimento de Jesus atraísse a ira romana sobre Jerusalém; então, liderados pelo sumo sacerdote Caifás, optaram por condená-lo (cf. Jo 11,45-54). Logo, pensar que todos os judeus de Jerusalém fossem coletivamente culpados da morte de Jesus não condiz com os dados bíblicos (cf. Mc 15,6-15; Lc 23,27; Jo 19,6). Notemos ainda que muitos

\footnotetext{
${ }^{6}$ Este documento é citado pelo título abreviado Notas. Para o texto integral cf. COMISSÃO PARA AS RELAÇÕES RELIGIOSAS COM O JUDAÍSMO, 1985.
} 
judeus aderiram à pregação de Jesus e constituíram as primeiras comunidades cristãs da Palestina e Ásia Menor. Sua herança perdura na teologia e liturgia cristãs: a oração dos Salmos, os ritos de batismo e ceia eucarística, o lecionário bíblico que integra a Torá, os Salmos e os Profetas; as Horas litúrgicas e o Dia da Páscoa segundo o calendário lunar; a compreensão de Aliança, Povo de Deus, ressurreição e salvação elementos assimilados pelos cristãos helenistas a partir do Judaísmo.

\section{b) Nós recordamos - uma reflexão sobre a Shoah (1998) ${ }^{7}$}

Documento de grande sensibilidade diante do Holocausto, designado em hebraico como Shoah (extermínio). Foi elaborado pela Comissão para as Relações Religiosas com o Judaísmo, no pontificado do Papa João Paulo II, que assina o preâmbulo. A Reflexão sobre a Shoah se organiza em cinco tópicos e reflete a tradição judaica do memorial (zíkaron): recordação e discernimento dos fatos, apelo à conversão e renovação da Aliança com Deus.

O documento admite a participação de católicos nas manifestações antijudaicas e demais "sofrimentos do povo judeu durante a Segunda Guerra Mundial" - como diz o Papa João Paulo II (RSh, Preâmbulo). Diz ainda: "Ao nos preparar para o início do Terceiro Milênio da Era Cristã" - então em 1998 - a Igreja "encoraja seus filhos e filhas a purificarem seus corações mediante o arrependimento pelos erros e infidelidades do passado"; mas também os convoca "a examinar-se sobre a responsabilidade que também têm pelos males do nosso tempo" (RSh, Preâmbulo). Lidas sob a memória do Holocausto, essas palavras admitem, portanto, a culpa de católicos nos modernos eventos antissemitas. Em seguida, o documento é incisivo: o Holocausto foi uma "tragédia que jamais poderá ser esquecida", um "horrível genocídio", um dos "principais dramas da História deste século [o séc. XX], um fato que ainda hoje nos diz respeito" (RSh n. 1). Portanto,

[...] é justo que a Igreja assuma com maior consciência o peso do pecado de seus filhos, recordando todas as circunstâncias em que, no arco da História, eles se afastaram do espírito de Cristo e de seu Evangelho, oferecendo ao mundo, em vez do testemunho de uma vida

\footnotetext{
7 O documento Nós recordamos - Uma reflexão sobre a Shoah é citado com a sigla RSh. Para o texto integral cf. COMISSÃO PARA AS RELAÇÕES RELIGIOSAS COM O JUDAÍSMO, 1998.
} 
inspirada os valores da fé, o espetáculo de modos de pensar e agir que eram verdadeiras formas de anti-testemunho e escândalo. (RSh n. 1)

Importa, pois, examinar "a questão do relacionamento entre a perseguição nazista e as atitudes dos cristãos, ao longo dos séculos, em relação aos judeus" (RSh n. 2); pois "o balanço dessas relações durante esses dois milênios foi bastante negativo" (RSh n. 3). Prosseguindo, o mesmo tópico III reconhece que "os sentimentos de antijudaísmo" tomaram formas violentas como "discriminação, expulsões e conversões forçadas", a agravar-se ainda mais com o "nacionalismo exasperado e falso" sustentado nas "teorias que negavam a unidade da raça humana, afirmando uma originária diferença das raças" (RSh n. 3). Aqui, o termo raça equivale a "gênero humano", no sentido de que "todos os povos constituem uma só comunidade humana" (NA n. 1). Ou seja, se diz raça em perspectiva inclusiva, como geração humana à qual pertencem todos as nações (= etnias, no grego de Mt 28,19). Neste sentido, a Reflexão sobre a Shoah condena a "idolatria da raça [ariana] e do Estado" promovida pela "ideologia nacional-socialista" (RSh n. 4 e 5, respectivamente). Mais adiante, o n. 4 volta a admitir a culpa de católicos nas hostilidades contra os judeus e reitera a posição atual da Igreja: "deplora todos os ódios, perseguições e manifestações de antissemitismo, seja qual for o tempo em que isso sucedeu e seja quem for a pessoa que promoveu isso contra os judeus" (RSh n. 4).

\section{c) O povo judeu e suas Sagradas Escrituras na Bíblia cristã (2002) ${ }^{8}$}

Este documento é mais volumoso que os anteriores, elaborado com acurada pesquisa histórica, exegética, teológica e hermenêutica. Intitulado $O$ povo judeu e suas Sagradas Escrituras na Bíblia cristã (2002), foi escrito pelos peritos da Pontifícia Comissão Bíblica, levando em conta a reflexão sobre o Judaísmo e o Holocausto desenvolvida pela Comissão para as Relações Religiosas com o Judaísmo. O documento retoma metodicamente as questões histórico-teológicas levantadas por Jules Isaac, Abraham Heschel, o American Jewish Committee e, mais recentemente, pelo International Council of Christians and Jews (cf. ICCJ, 2011). Assim, a antiga

\footnotetext{
8 O documento O povo judeu e suas Sagradas Escrituras na Bíblia cristã é citado com a sigla JEB. Para o texto integral cf. PONTIFÍCIA COMISSÃO BÍBLICA, 2002.
} 
acusação de deicídio, a tese da maldição e a teoria da substituição de Israel pela Igreja - já refutadas na breve redação de Nostra Aetate n. 4 - ganham abordagem mais cuidadosa em termos bíblicos, históricos e teológicos, no quadro de uma ampla reflexão sobre a Divina Revelação e sua recepção da parte de judeus e cristãos. Afirmam-se a perenidade da Aliança e os estreitos vínculos entre Israel e a Igreja, com explanação dos temas teológicos em continuidade, descontinuidade ou com desenvolvimentos específicos no judaísmo e no cristianismo. Isto é feito em três longas seções, arrematadas por uma Conclusão geral:

I - As Escrituras do povo judeu, parte fundamental da Bíblia cristã

II - Temas fundamentais das Escrituras judaicas e sua acolhida na fé em Cristo

III - Os judeus no Novo Testamento

A Seção I examina as relações entre o Antigo e o Novo Testamentos, demonstrando seus pontos de continuidade, descontinuidade e progressão. Os textos cristãos não partem do zero, mas seguem a teologia da Aliança e a tradição profética de Israel, nunca negando as alianças anteriores, mas considerando-as realizadas por Jesus. Crendo-o como Messias, os judeo-cristãos da Igreja nascente interpretaram a Torá e o culto à luz do Evangelho, como expressão do movimento judaico dos discípulos do Nazareno. Assim, as Escrituras judaicas são integradas aos conteúdos e ao volume da Bíblica cristã.

Teologicamente, muitos temas da fé de Israel encontram acolhida e evolução no Novo Testamento, como demonstra a Seção II: a Revelação de Deus, a pessoa humana como sujeito da graça divina, a fé no Deus santo e libertador, a Aliança estabelecida desde Abraão; a noção de Povo de Deus e Reino de Deus; o papel pedagógico da Torá e o culto litúrgico ao Deus Único, as admoestações divinas para a conversão e Suas promessas. O documento esclarece que judeus e cristãos do século I esperavam a salvação de Israel, que se mantinha como povo eleito por Deus. Jesus sinaliza isso ao escolher Doze apóstolos, judeus com Ele, em referência às Doze tribos de Israel. Além disso, Israel era tido como sinal da misericórdia de Deus aos gentios, ou seja, os demais povos, conforme os capítulos de Rm 9-11 (cf. JEB seção I, n. 23-61).

A Seção III é particularmente esclarecedora, por contextualizar os juízos negativos a respeito de alguns judeus no Novo Testamento. Antes de tudo, a pluralidade de Judaísmos naquele período mostra que não se pode reduzir os debates 
de Jesus e dos Apóstolos a um esquema binário, de simples oposição. Desde a reforma de Esdras (444 a.C.) até a devastação de Jerusalém pelo exército romano (70 d.C.), desenvolveu-se o chamado Judaísmo do Segundo Templo, com diferentes perspectivas quanto à Torá, o Templo e a esperança do Messias. No séc. I d.C. Flávio Josefo descreveu os três partidos mais influentes: saduceus, fariseus e essênios. Esses grupos são descritos no documento, com relação ao contexto histórico e religioso de Jesus e dos apóstolos (cf. JEB seção III, n. 66-70).

A coexistência desses grupos judaicos era, por vezes, tensa e conflitiva. Havia um ambiente de discussão religiosa e política sobre o valor do Templo, o relacionamento com os romanos, as concepções de Reino de Deus e o perfil do Messias esperado. Esse contexto se reflete em várias cenas do Evangelho, em que há discussões entre saduceus, fariseus e Jesus sobre a função do Templo, a interpretação da Lei e sua própria identidade como mestre e pregador. Notemos que isto ganha coloração de controvérsia depois da destruição de Jerusalém pelos romanos (70 d.C.), quando as primeiras comunidades cristãs vão conviver, de um lado, com os judeus da diáspora; de outro, com os gentios que aderem ao Evangelho. Afinal, até o séc. II os discípulos de Jesus eram, em grande parte, judeo-cristãos de cultura semita. Do séc. III ao IV os gentios se tornam maioria entre os cristãos; os discípulos de origem judaica decrescem; em consequência, acirram-se as distinções entre os cristãos-helênicos e as Sinagogas, geralmente dirigidas por fariseus. Tudo isso deve ser considerado na leitura das Escrituras e da Patrística, evitando-se reducionismos e oposições simplistas que fazem dos judeus, sem distinção, inimigos da fé cristã (cf. JEB seção III, n. 76-83).

\section{d) Porque os dons e o chamado de Deus são irrevogáveis (2015) 9}

Publicado no pontificado de Papa Francisco, o documento Porque os dons e o chamado de Deus são irrevogáveis (2015) celebra os 50 anos da Declaração Nostra Aetate. Por isso, abre-se com o balanço dos 50 anos de recepção e desenvolvimentos

\footnotetext{
${ }^{9} \mathrm{O}$ documento Porque o chamado e os dons de Deus são irrevogáveis é citado com a sigla DCI. Para o texto integral cf. COMISSÃO PARA AS RELAÇÕES RELIGIOSAS COM O JUDAÍSMO, 2016.
} 
desta Declaração conciliar (cf. DCl Parte I, n. 1-13). Em seguida, discorre sobre "o estatuto teológico específico do Diálogo judaico-católico" (DCI Parte II, n. 14): na agenda ampla do diálogo inter-religioso que a Igreja Católica anima e realiza, com o Budismo, o Hinduísmo, as Religiões tradicionais da África, o Islã e outras, o Diálogo com o Judaísmo se distingue pelo teor teológico do patrimônio de fé em comum com o Cristianismo. "Não obstante a ruptura histórica [entre judeus e cristãos] e os dolorosos conflitos que disso derivaram, a Igreja está consciente de sua permanente continuidade com Israel" (DCI Parte II, n. 14). De fato, Judaísmo e Cristianismo mantêm estreitos vínculos culturais, éticos e teológicos, reconhecidos e explicitados reciprocamente nos cinquenta anos de Diálogo Internacional, desde a publicação de Nostra Aetate. O Diálogo judaico-católico favoreceu relações de confiança e de partilha quanto ao futuro comum das duas religiões abraâmicas.

As partes III, IV, V e VI do Documento tratam, respectivamente, de quatro questões teológicas delicadas, pois sua compreensão afeta o relacionamento e o reconhecimento mútuo de judeus e cristãos. Citamos aqui as linhas essenciais dessas questões:

1) Antigo e Novo testamentos são duas recepções da mesma Palavra de Deus:

O Judaísmo e a fé cristã, tal como são apresentados no Novo Testamento, são dois modos pelos quais o Povo de Deus apropria-se das Sagradas Escrituras. [...] Uma resposta à Palavra salvífica de Deus que esteja em fidelidade a uma ou outra tradição pode, portanto, dar acesso a Deus - ainda que se reserve à intervenção de Deus determinar em que modo Ele intenda salvar as pessoas que se encontrem nessas duas circunstâncias. Afinal, que a vontade salvífica de Deus destina-se a toda a humanidade é fato testemunhado pelas Escrituras (cf. Gn 12,13 ; Is 2,2-5; $1 \mathrm{Tm} 2,4$ ). Portanto, não há duas estradas diferentes que levam à salvação, segundo o mote "os judeus são fiéis á Torá, os cristãos, a Cristo". A fé cristã professa que a obra salvadora de Cristo é universal, destinando-se a todos os seres humanos. A Palavra de Deus é uma realidade única e indivisa, que assume uma forma concreta no contexto histórico cada um, judeu e cristão. (DCI Parte III, n. 25)

2) A antiga Aliança, desde Abraão, ainda é válida para os cristãos da nova Aliança:

[...] deve ficar claro aos cristãos que a Aliança contraída por Deus com Israel, em virtude da inabalável fidelidade de Deus a seu Povo, jamais foi revogada e, portanto, permanece válida. Consequentemente, a Nova Aliança na qual creem os cristãos só pode ser compreendida como confirmação e cumprimento da Antiga. Nesta mesma linha de argumento, os cristãos são convictos de que, mediante a Nova Aliança, a aliança abraamita alcançou aquela universalidade que visava a todos os povos, originalmente anunciada na vocação de Abraão (cf. Gn 12,1-3). Esta referência à aliança abraamita é um elemento tão constitutivo da fé cristã, 
que, sem Israel, a Igreja arriscaria perder o seu lugar na História da Salvação. (DCI Parte IV, n. 33)

3) Deus não revogou o chamado e as promessas feitas ao povo de Israel:

Note-se que a confissão cristã de que há uma só via salvífica não é suficiente para excluir os judeus da salvação de Deus, pelo fato de não terem crido em Jesus como Messias de Israel e Filho de Deus. Uma tal afirmação não encontra fundamento na visão de Paulo sobre a salvação: na Carta aos Romanos, ele não só exprime sua convicção de que não há rupturas na história da salvação, mas também a convicção de que a salvação vem dos judeus (cf. também Jo 4,22). Deus confiou a Israel uma missão única e não cumprirá seu misterioso plano de salvação destinado a todos os povos (cf. 1Tm 2,4) sem incluir o seu "filho primogênito" (Êx 4,22). Vemos claramente que, na Carta aos Romanos - quando Paulo indaga se acaso Deus tinha rejeitado o seu Povo - ele mesmo responde com firme negação (Deus não rejeitou Israel). A resposta de Paulo traz uma decidida afirmação: "Porque os dons e o chamado de Deus [para Israel] são irrevogáveis" (Rm 11,29). (DCI Parte V, n. 36)

\section{4) Como entender a evangelização dos judeus, por parte dos cristãos?}

A Igreja deve, portanto, compreender a evangelização destinada aos judeus - que creem no Deus único - de maneira distinta da evangelização dirigida àqueles que pertencem a outras religiões ou têm outras visões de mundo. Isto significa concretamente que a Igreja Católica não lidera nem encoraja qualquer missão institucional voltada especificamente aos judeus. Enquanto recusa firmemente - por princípio - uma missão institucional dirigida aos judeus, exorta os cristãos a dar testemunho da sua fé em Jesus Cristo também aos mesmos judeus; contudo, os católicos deverão fazê-lo com humildade e sensibilidade, a reconhecer que os judeus são portadores da Palavra de Deus e a recordar, sempre, a grande tragédia da Shoah [Holocausto]. (DCI Parte VI, n. 40)

Esta última questão é de suma importância, porque a conversão dos judeus era uma bandeira intransigente da Cristandade, a justificar confiscos, expulsões e batismos forçados de milhares de judeus (cf. SCHLESINGER; PORTO, 1975, p. 117-136). À conclusão, o documento confirma o diálogo judaico-católico do presente com vistas ao futuro, com três objetivos: aprofundar o conhecimento recíproco entre hebreus e cristãos; comprometer-se juntos a favor da justiça, da paz, da salvaguarda da Criação e da reconciliação mundial; reagir contra toda discriminação racial referente aos hebreus, bem como qualquer forma de antissemitismo que, por certo, não foi ainda plenamente erradicado e aflora com expressões diferentes, em contextos diferentes (DCI Parte VII, n. 44-47).

Considerações finais 
O processo de revisão histórico-teológica suscitado pelo Diálogo JudaicoCatólico, desde as interlocuções em preparação do Concílio Vaticano II, resultou em muitos frutos: confiança e colaboração entre líderes judeus e católicos, consolidação de canais permanentes de diálogo e representação, tomada de posição comum a favor dos direitos humanos, interação no estudo e no ensino da Sagrada Escritura, correção de discursos e publicações que manifestavam ódio recíproco, diretrizes para a ação e a educação das respectivas comunidades, celebrações conjuntas da memória e do patrimônio teológico partilhado, conexões com outras Confissões cristãs e o diálogo inter-religioso.

Dois fatos, porém, merecem destaque por seu teor e suas consequências: a consciência do Holocausto, da parte de judeus e cristãos; e a consciência judaica da própria Igreja. Ainda que as controvérsias judaico-cristãs sejam matéria secular - sem negar os casos de respeito, defesa e apreço dos judeus por parte de cristãos nos diferentes períodos históricos - a Shoah (extermínio) foi um evento sem precedentes, que marcou dramaticamente as consciências, os comportamentos e as iniciativas desde que veio a conhecimento público, no final da Segunda Guerra. Em boa medida, podemos dizer que os recentes frutos do diálogo católico-judaico brotam da consciência sempre alerta e disposta ao bem, em reação aos horrores do Holocausto.

Por outro lado, a consciência judaica da Igreja - no sentido de rememorar e reconhecer suas raízes judaicas e a herança milenar do Judeo-Cristianismo primitivo tem sido o elemento faltante mais grave, do ponto de vista histórico e teológico. Não só pelas consequências que seu esquecimento trouxe, com a escalada virulenta do sentimento antijudaico ao longo dos séculos, mas pelos danos causados à própria identidade cristã do Ocidente. Com efeito, o esquecimento das raízes judaicas da Igreja prejudicou a judeus e a cristãos; e certamente seu reconhecimento favorece igualmente a ambos, como os Documentos analisados nos fazem notar.

Enquanto a consciência do Holocausto funciona em chave negativa - como evento a ser lembrado e repudiado seguidamente, para que jamais volte a suceder - a consciência judaica dos cristãos passa pelo trauma do Holocausto e reenvia as Igrejas ao terreno comum da Aliança pelo Reino de Deus, onde encontramos Jesus, os apóstolos e os primeiros discípulos. A sábia articulação dessas duas consciências é 
como dois ponteiros a compassar a convivência judaico-cristã, no presente e no futuro que pretendemos construir, alicerçados na verdade, na justiça e na paz.

\section{Referências}

ANDREVON, Th.-M. Les Juifs et la préparation du texte conciliaire Nostra Aetate. Nouvelle Revue Théologique, Louvain, n. 135, p. 219-238, 2013.

ARENDT, H. Escritos judaicos. Barueri: Amarlys, 2016.

BAUMAN, Z. Modernidade e Holocausto. Rio de Janeiro: Zahar, 1998.

CENTRO CRISTÃO DE ESTUdOS JUDAICOS [CCDEJ]. Os Dez Pontos de Seelisberg. Disponível em: https://www.judaismoecristianismo.org/textos-fundamentais/266-os-dez-pontos-daconferencia-de-seelisberg. Acesso em: 15 set. 2020.

CONCÍLIO VATICANO II. Compêndio do Vaticano II. 22. ed. Petrópolis: Vozes, 1991.

CONCÍLIO VATICANO II. Declaração Nostra Aetate. In: CONCÍLIO VATICANO II. Compêndio do Vaticano II. 22. ed. Petrópolis: Vozes, 1991. p. 617-625 [numeração marginal 1578-1596].

COMISSÃO PARA AS RELAÇÕES RELIGIOSAS COM O JUDAÍSMO [1985]. Notas para uma correta apresentação dos Judeus e do Judaísmo na pregação e na catequese da Igreja Católica. In: BIZON, J.; DARIVA, N.; DRUBI, R. (orgs.). Diálogo inter-religioso. São Paulo: Paulinas, 2005. p. 330-344.

COMISSÃO PARA AS RELAÇÕES RELIGIOSAS COM O JUDAÍSMO [1998]. Nós recordamos Uma reflexão sobre a Shoah. In: BIZON, J.; DARIVA, N.; DRUBI, R. (orgs.). Diálogo interreligioso. São Paulo: Paulinas, 2005. p. 348-360.

COMISSÃO PARA AS RELAÇÕES RELIGIOSAS COM O JUDAÍSMO [2000]. Porque os dons e o chamado de Deus são irrevogáveis. Brasília: Edições CNBB, 2016.

DE LUBAC, H. Resistenza cristiana all'antissemitismo: Ricordi 1940-1944. Milano: Jaca Book, 1990.

DENZINGER, H. El magisterio de la Iglesia. Barcelona: Herder, 1997. (Sigla DZ).

GUNDLACH, G. Antissemitismus [verbete]. In: BUCHBERGER, M. (ed.). Lexikon für Theologie und Kirche [LTK]. 2. ed. Freiburg im Breisgau: Herder, 1930. p. 504-505.

GUNDLACH, G. Anschluss: sur l'annéxion. La Documentation Catholique, Paris, ano XX, tomo 39, n. 870, p. 451-474, 1938. (Réplica do artigo publicado em L'Osservatore Romano).

INTERNATIONAL COUNCIL OF CHRISTIANS AND JEWS [ICCJ]. Os Doze Pontos de Berlin. São Leopoldo: Oikos, 2011. 
ISAAC, J. Jesus e Israel. São Paulo: Perspectiva, 1986.

ISAAC, J. Las raíces cristianas del antisemitismo. Buenos Aires: Paidós, 1966. (Tradução do original francês L'enseignement du mépris, Paris: Éd. Fasquelle, 1962).

MARR, W. Der Weg zum Siege des Germanenthums über das Judenthum. Berlin: Otto Hentze Verlag, 1880.

MORIN, E. O mundo moderno e a questão judaica. Rio de Janeiro: Bertrand do Brasil, 2007.

PIO V, Papa. Missale Romanum ex decreto SS. Concilii Tridentini restitutum. 27. ed. Ratisbona: Friedrich Pustet Verlag, 1950.

PIO XI, Papa. Mit brennender sorge - Encíclica, 1937. Disponível em: http://www.vatican.va/content/pius-xi/es/encyclicals/documents/hf_p-xi_enc_14031937_mitbrennender-sorge.html. Acesso em: 10 set. 2020.

PASSELECQ, G.; SUCHECKY, B. A encíclica escondida de Pio XI. Petrópolis: Vozes, 1998.

PONTIFÍCIA COMISSÃO BÍBLICA [2002]. O povo judeu e suas Sagradas Escrituras na Bíblia cristã. In: BIZON, J.; DARIVA, N.; DRUBI, R. (orgs.). Diálogo inter-religioso. São Paulo: Paulinas, 2005. p. 361-528.

RIES, J. I cristiani e le religioni. Brescia: Queriniana, 1992.

SANTO UFFICIO. Acta Apostolicae Sedis vol. XX. Città del Vaticano: TPV, 1928.

SCHLESINGER, H.; PORTO, H. Anatomia do anti-semitismo. São Paulo: Loyola, 1975.

RECEBIDO: 29/09/2020

RECEIVED: 09/29/2020

APROVADO: 23/11/2020

APPROVED: $11 / 23 / 2020$ 